\title{
透析患者の精神症状に対応した看護について
}

\author{
舘 山俊子制 野真理子 田 沢 ハチエ \\ 鷹揚郷腎研究所弘前病院 \\ (昭和 60 年 12 月 11 日受付)
}

key words：長期透析患者, 精神症状, 面接看護

〈要旨〉

私達は現在まで, 精神科医による面接を基本としてその際に認められた精神症状に対し, 医療スタッフがどのよう な接し方をするのが最適かの助言を受け看護計画を作成し，また補助的に薬物投与も行って対処してきた，この方法 により大部分の症例は顕著な精神症状の改善をみることができたが, これらの症例のうちとくに私達看護スタッフに とって考えさせられる事の多かった 5 症例について, 面接時の精神症状の推移やこの間に行われた看護の展開などに ついて考察した。

症例 1 は妻子から見捨てられ，夫としての役割喪失が問題となった例であり，このような症例に対しては家族への 積極的な働きかけが大切であり, 本症はこれにより精神症状が改善した. 症例 2 は家族内の精神病の甥の存在が不定 愁訴をきたす最大の原因と考えられ，患者のもつ問題点をいかに早く見い出すかが重要であると改めて考えさせられ た例である. 症例 3 は医療スタッフの治療態度に不信感を抱いた例で, 医療スタッフ間での話し合いにより, 統一し た見解をもって対応していくことで不信感がとり除かれた例である. 症例 4 はたび重なる合併症の出現が問題となっ た例で, このような症例に対しては, 合併症に対する治療を優先することが精神症状の改善を計る事ができる唯一の 方法であることを痛感させられた。 症例 5 は身体が小さく病気をもっている, という劣等感を有しながら恋愛感情を いだいたのを契機に発症した例で, 年齢にみあった対応が必要であることが示された。

以上の 5 症例は私達の経験したほんの一部にすぎないが, 様々な問題が根底にあり, 弚れに伴って出現する精神症 状の変化を私達医療者は正確にとらえ，炎の原因を十分に理解して対応することが重要である.

\section{Nursing according to the mental state of patients on chronic hemodialysis}

Toshiko Tateyama, Mariko Seino, Hachie Tazawa

Oyokyo Kidney Research Institute, Hirosaki Hospital

We undertook a nursing project, based on psychiatric advice, with drug administration as supplemental treatment. The mental states of almost all patients became favourable in this project. We report 5 cases of mental states that improved in our project, according to psychiatrist's interview, and have tried to develop a project based on our experiences. Case 1. This patient lost his role as a husband because he was deserted by his wife and children. His mental state was improved by our active consultation with his family. Case 2. This patient was troubled by his nephew who had a mental disorder. In this case, it was necessary to find the cause of the mental problem as soon as possible. Case 3 . This patient had no confidence in the medical staffs and the treatment. We discussed the treatment with him and he came to have the same opinion in favor of it. His skepticism was removed in this way. Case 4. This patient had had frequent physical complications which caused a mental disorder. In this case, the treatment of his complications led to his mental improvement. Case 5. This patient had had an inferiority complex concerning his figure and disease. He showed mental symptoms when he expressed affection for some woman. It was important that we gave him treatment suitable to his age. These 5 cases are only a few of the patients with various mental problems. It is important for us to nurse the patient with recognition of the changes in their mental states and with sufficient understanding of the causes.

舘山 俊子 鷹揚鄉腎研究所弘前病院

T 036 弘前市小沢字山崎 90 (0172-87-1221) 


\section{はじめに}

透析患者は，様々な精神症状を示し，特に抑うつ状態 に陥りやすく，時には怒りや攻撃性，強い焦燥感などを 示し，私達医療スタッフを困らせることも稀ではない。 このような精神症状の出現する背景やその対応について はすでに当院の平山市らが報告しているが，その中で特 に医療スタッフ間での意志の統一が重要なポイントであ ると考えられた。そこで私達は現在まで，精神科医によ る面接を基本として，医療スタッフがどのような接し方 をするのが最適かの助言を受け，看護計画を作成し，ま た，補助的に薬物投与も行って対処してきた。この方法 により大部分の症例は顕著な精神症状の改善をみること ができたが，中には次々と多彩な精神症状を呈する例も あり，10症例のうち特に私達看護スタッフにとって考元 させられることの多かった 5 症例を呈示し，面接時の精 神症状の推移やこの間に行われた看護の展開などについ て述べ，精神症状に対応した看護のあり方について考え てみた。

\section{症例}

症例 1 ： 45 歳, 男性.

家族背景：母，妻，子供 2 人。

現病歷：35 歳時糖尿病を某医にて指摘されインシュ リン療法開始. 昭和 57 年全身浮腫出現. 下肢倦急感, $B U N, K$ 上昇等のため当院に入院し，糖尿病性腎症によ る慢性腎不全として 42 歳時の昭和 57 年 12 月より血液 透析療法を開始した。

経過：患者は日頃から活気がみられず，常にうつむき 加減で悩みをもっている様子が見受けられた。また両下 肢痛を訴え歩行器を使用し，思うように外泊できないた めか家族の面会を心待ちにしていた。しかし，母の面会 はあるものの, 妻子の面会はなく日毎に表情が暗くなり， 無口になってきたため透析導入 2 力月前に第 1 回目の面 接を行った。表 1 は本例の経過を示したものである.
初回面接時，不眠，焦燥感が現われており，意欲がみ られず，抑うつ状態と診断され，抗うつ剤，眠剤が投与 された。服薬後は少し落ち着いたのか時々笑顔がみられ るようになり，良く眠れるようになったといっていたが， 家族のこと経済的なことを考えると，夜，時々目覚める ときがあると言っていたことから 11 月 5 日 2 回目の面 接を行った. 初回面接時より抑うつ状態はやや軽隇した が，まだ心気的であるため，家族の面会を増すようにと の精神科医よりのアドバイスを受けた。家族の関係など について話をきいてみたところ，妻子にはまったく面会 にくる意志がないことがわかった。しかし，母親は息子 が心配で時々面会にくるようであり，患者もその母親に 甘えている様子が見受けられ，母親の面会により患者は 少し落ち着いてきたように思われた。

翌年 6 月頃から急に両膝を強く屈曲できずこのまま歩 けなくなるのではと不安を訴えるようになり，考えこむ 姿を見受けるようになったため, 3 回目の面接を行った。 面接時, 自殺念慮, あきらめ, 悲観などの症状が現われ て招り，足の痛みを急に訴えだしたのは，家族との関係 がうまくいかないためと考えられたことから，私達は妻 子の面会を依頼したが，仕事が忙しい等の理由でくる気 配はなかった。その後も下肢痛の訴光は続き，4回目面 接では安定棛が投与されたが，次第に夜間の徘徊が頻繁 になり，トイレの便槽に紙を詰める等の異常行動を現わ すようになった。 5 回目面接では抑うつ，悲観，自殺念 慮が現われ眠剂が増量され，家族の面会を再度要請する ようにとのアドバイスを受け，私達も再三面会を要請し たが，相変わらず忙しいという返事であった，患者は母 親が時々面会にくることで少しは落ち着きをみせるよう になり，また電話をかけているのをみかけることもあっ た．日毎に足の痛みもとれてきたためか外泊するように なったものの，暗い表情が目につき，話しかけても「楽 しくない」と一言言うだけであった。そこで 6 回目面接

表 1 面接時の精神症状と経過（症例 1)

\begin{tabular}{|c|c|c|c|c|c|c|}
\hline 面接回数 & $\begin{array}{c}1 \\
\text { ( S } 57.10 .29)\end{array}$ & $\begin{array}{c}2 \\
\text { (S } 57.11 .5)\end{array}$ & $\begin{array}{c}3 \\
\text { (S } 58.7 .1 \text { ) }\end{array}$ & $\begin{array}{c}4 \\
\text { (S } 58.8 .12)\end{array}$ & $\begin{array}{c}5 \\
\text { (S } 59.2 .3 \text { ) }\end{array}$ & $\begin{array}{c}6 \\
\text { (S 59.9.5) }\end{array}$ \\
\hline 心理状況 & $\begin{array}{l}\text { 焦燥感 } \\
\text { 抑うつ状態 } \\
\text { 不 眠 }\end{array}$ & $\begin{array}{l}\text { 抑うつ } \\
\text { 心気的 }\end{array}$ & $\begin{array}{l}\text { 自殺念慮, あきらめ } \\
\text { 死の不安, 怒り } \\
\text { 悲観, 焦燥感 }\end{array}$ & $\begin{array}{l}\text { 抑うつ状態 } \\
\text { 焦燥感, 怒り } \\
\text { 死の不安 }\end{array}$ & $\begin{array}{l}\text { 抑うつ, 悲観 } \\
\text { 自殺念慮 } \\
\text { 問題行動出現 }\end{array}$ & $\begin{array}{l}\text { 妻子との断絶 } \\
\text { 父親として威舼消失 } \\
\text { 離婚の不安 }\end{array}$ \\
\hline $\begin{array}{l}\text { 精神科医の } \\
\text { アドバイス }\end{array}$ & $\begin{array}{l}\text { 抗うつ剂 投与 } \\
\text { 眠 剂 接 }\end{array}$ & 家族の面会を増す & 家族の面会を増す & 安定剂の併用投与 & \begin{tabular}{|l|} 
眠剤の増量 \\
家族の面会再度要請
\end{tabular} & $\begin{array}{l}\text { 妻, 母親を呼び面会 } \\
\text { 状況説明と要請 }\end{array}$ \\
\hline 対 応 & & 家族の状沉チェック & $\begin{array}{l}\text { バスで外泊できるまで } \\
\text { 妻, 子供の面会を依頼 }\end{array}$ & & $\begin{array}{l}\text { ケースワーカーから } \\
\text { 家族へ面会を要請 }\end{array}$ & $\begin{array}{l}\text { 妻, 母親を呼び面会 } \\
\text { (主治医, 婦長, ケー } \\
\text { スワーカー） }\end{array}$ \\
\hline 結 果 & & $\begin{array}{l}\text { 妻, 子供の面会の意志 } \\
\text { なし }\end{array}$ & & 母親が面会 & 面会なし & $\begin{array}{l}\text { 妻 受け入れるよう } \\
\text { 努力する }\end{array}$ \\
\hline
\end{tabular}


表 2 面接時の精神症状と経過（症例 2);

\begin{tabular}{|c|c|c|c|c|c|c|}
\hline 面接回数 & $\begin{array}{c}1 \\
\text { (S } 57.3 .12)\end{array}$ & $\begin{array}{c}2 \\
\text { (S 57.11.6) }\end{array}$ & $\begin{array}{c}3 \\
\text { (S } 58.1 .21) \\
\end{array}$ & $\begin{array}{c}4 \\
\text { (S } 58.1 .28)\end{array}$ & $\begin{array}{c}5 \\
\text { (S } 58.2 .4) \\
\end{array}$ & $\begin{array}{cc}6 & 10 \\
(\mathrm{~S} 59.1 .20 \sim \mathrm{S} & 60.7 .19) \\
\end{array}$ \\
\hline 心理状態 & $\begin{array}{l}\text { 抑うつ状態 } \\
\text { 焦燥感, 怒り }\end{array}$ & 幻覚, 妄態状態 & $\begin{array}{l}\text { 不眠, 食欲低下, } \\
\text { 体重減少 }\end{array}$ & 心気状態 & 抑うつ状態軽減 & $\begin{array}{l}\text { 精神病の甥の同居判明 } \\
\text { 心気状態, 抑うつ状態悪 } \\
\text { 化 }\end{array}$ \\
\hline $\begin{array}{l}\text { 精神科医の } \\
\text { アドバイス }\end{array}$ & 抗うつ剂の投与 & $\begin{array}{l}\text { 患者の話を良く聞く } \\
\text { 精神安定剤の投与 }\end{array}$ & $\begin{array}{l}\text { 主治医とのコミュニ } \\
\text { ケーションを良くする } \\
\text { 抗うつ剤, 眠剤投与 }\end{array}$ & $\begin{array}{l}\text { 主治医, 看護婦が } \\
\text { 患者に注目してい } \\
\text { る事を態度で示す }\end{array}$ & 合併症に対応 & 蝟を精神病院で治療導入 \\
\hline 対 応 & & $\begin{array}{l}\text { 患者と接する時間を } \\
\text { 少しでも多くする }\end{array}$ & $\begin{array}{l}\text { 身体症状の訴えに対 } \\
\text { し主治医から説明し } \\
\text { てもらう }\end{array}$ & \multicolumn{2}{|c|}{$\begin{array}{l}\text { 身体症状の訴えに対し主治医か } \\
ら \text { 説明してもらう }\end{array}$} & $\begin{array}{l}\text { 侽の精神病院での治療を } \\
\text { 家族に働きかける }\end{array}$ \\
\hline 結 果 & & $\begin{array}{l}\text { 様々な身体症状を訴 } \\
\text { えるようになる }\end{array}$ & & \multicolumn{2}{|c|}{$\begin{array}{l}\text { 医師, 看護婦が一生懸命自分の } \\
\text { 病気を治してくれていると喜ん } \\
\text { でいる }\end{array}$} & \\
\hline
\end{tabular}

を行うこととなり，「家にいても楽しくない」「妻子が一 緒に食事をしない」等と患者がいっていることから妻子 との断絶が生じていたことがわかった。そこで主治医, 看護婦, ケースワーカーが妻, 母と話し合いをもち, 妻 から，家族に扔いては夫，父親として暖かい目で迎え入 れるよう努力しますという言葉があった。 その後, 患者 が外泊した時には妻は一緒に食事をするようになった が，子供達は言葉をかわすものの自分達の部屋に入って しまう状況が続いている，子供達が父親として患者を迎 え入れるにはまだ時間がかかりそうであるが，患者は少 しずつ家族の態度が変ってきたため, 週 1 回外泊するよ うになった。

\section{症例 2： 53 歳, 女性.}

家族背景：夫，姑，子供 3 人，甥(夫の弟の子供).

現病歴：48 歳時の昭和 55 年, リウマチ, 慢性腎炎を某 医にて指摘される。昭和 56 年軽度 BUN 上昇を認め当院 に通院治療していたが, 昭和 57 年 7 月悪心, 澏吐の出現, BUN, クレアチニンの上昇などを認め入院，9月 14 日よ り血液療法を開始した。

'経過：患者はいつも暗い表情をしており，様及な身体 症状をくり返し訴えるのが続いた。特に外泊をし㷌院し た後の訴えは，ぐちをこぼしているようであり，表情が 暗いのが目についたことから第 1 回目の面接を行った. 表 2 は本例の経過を示したものである.

初回面接は透析導入前で, 家庭のこと, 経済的なこと では心配することがなく，いつ透析に入るのかそれだけ が心配だと言っており, 抑うつ, 焦燥, 怒りが現われ, 抗うつ剤が投与された。 その後も BUN 上昇を認め, 昭 和 57 年 9 月 14 日透析導入となり精神的に不安定な状態 が続いたために，2 回目面接を行った。この面接では透 析中に夫，娘の声が聞こえてきたと幻覚，妄想状態が現
われていた．精神安定郕が投与され，患者の話を良く聞 くようにとのアドバイスを受け，私達はできるだけ患者 と接する時間を多くもつようにこころがけた，その後， 食思不振，体重減少を認めたことなどから患者は癌では ないかと疑いをもつようになり，不眠が続き 3 回目面接 を行った。この面接ではさらに抗うつ剤，眠剤が投与さ れ主治医とのコミュニケーションを良くするようにとの アドバイスがあり，身体症状の訴えに対し患者の傍にい き説明するような対応をした。しかし，「腹がチクチクと 時々痛む」，「口の中が苦い」等と身体的不調の訴光が続 いたため, 1 週間後 4 回目面接を行ったが, 3 回目面接 時より精神症状が悪化しているようで心気状態と診断さ れた。主治医，看護婦が患者に注目していることを態度 で示すようにとのアドバイスがあり，主治医と話し合っ た結果，患者を安心させるために検査などすることで癌 ではないことの不安をとり除けるのではないかというこ とで検查を行ってみることになった，その結果，約 1 力 月後の 5 回目面接では抑うつ状態が軽減しており,「今日 は癌を心配していない」と少し表情に明るさがみられる ようになった。しかし，その後も不定愁訴が続き，6回 〜 回目面接までは抑うつ状態の悪化, 軽減をくり返し 抗うつ剤，眠殽などがその都度投与された，その後，患 者から面接したいとの希望があり，昭和 60 年 7 月 19 日 10 回目面接を行った。面接時, 精神病の甥が同居してい ることがわかり，「姑が甥をかわいがる」「働かない侽が ブラブラと家にいる」「夫に訴えてもとりあってくれな い等の原因で，精神病が悪化していたことが判明した。 侽を精神病院で治療することにより, 患者の精神症状も 軽滅されるのではないかとのアドバイスを受け，ケース ワーカーを通じ，少し介入しすぎるのではとの懸念を感 じながら，現在家族に働きかけているところである. 
表 3 面接時の精神症状と経過（症例 3)

\begin{tabular}{|c|c|c|c|c|c|}
\hline 面接回数 & $\begin{array}{c}1 \\
\text { (S 57.2.19) }\end{array}$ & $\begin{array}{c}2 \\
\text { (S 57.3.12) }\end{array}$ & $\begin{array}{c}3 \\
\text { (S 59.11.9) }\end{array}$ & $\begin{array}{c}4 \\
\text { (S 59.11.16) }\end{array}$ & $\begin{array}{c}5 \\
\text { (S } 59.12 .7 \text { ) }\end{array}$ \\
\hline 心理状態 & $\begin{array}{l}\text { 焦燥, 怒り, 攻撃 } \\
\text { 抑うつ, 悲観 } \\
\text { 自殺念慮, 心気状態 }\end{array}$ & 抑うつ状態軽滅 & 夫の死L & 精神症状軽減 & 心気状態 \\
\hline $\begin{array}{l}\text { 精神科医の } \\
\text { アドバイス }\end{array}$ & $\begin{array}{l}\text { 医師, 看護婦の見解 } \\
\text { の統一 }\end{array}$ & 抑うつ剤投与 & $\begin{array}{l}\text { 看護者が良く話を聞く } \\
\text { 眠剂，抗うつ剂投与 }\end{array}$ & & 主治医が良く話を聞く \\
\hline 対 応 & $\begin{array}{l}\text { 患者と接する時 } \\
\text { 検查処置の説明! }\end{array}$ & $\begin{array}{l}\text { 氞を多くする } \\
\text { さ十分にする }\end{array}$ & & & \\
\hline 結 果 & & $\begin{array}{l}\text { 患者から笑顔が } \\
\text { みられるように } \\
\text { なった }\end{array}$ & & \multicolumn{2}{|c|}{$\begin{array}{l}\text { 患者からすすんで } \\
\text { 話しかけるようになった }\end{array}$} \\
\hline
\end{tabular}

\section{症例 3： 53 歳, 女性.}

家族背景 : 夫 (別居 $\rightarrow$ 死亡), 子供 2 人.

現病歴：昭和 51 年某医にて囊胞腎を指摘され, 当院に 16 日間入院，精査を受けたが以後時折来院するのみで あった。昭和 56 年 9 月眩暈, 腰痛などが出現し, 当院に 再入院した。この間, 数力所の医療機関を転々としてい たとのことであった。昭和 59 年 10 月になり両手のしび れ感, BUN, クレアチニン值の上昇等を認め入院, 昭和 59 年 11 月 1 日より血液透析療法を開始した。

経過：以前入院していた病院で医療スタッフが患者の 前で不用意な発言をしたことと検査の説明が不十分で あったことなどから，腎臟が悪くなったのは検査のため だと思い込み，医療者に対し強い不信感をもつように なった，患者は無口で話しかけても返事はするものの， なかなか自分から口を開こうとはせず，私達も対応には とまどうことが多い症例であった。表 3 は本例の経過を 示したものである。

初回面接では, 焦燥, 怒り, 攻撃, 抑うつが強く現わ れており, 以前入院していた病院での検查のことなども 一気に話した、そこで医師, 看護婦の意志を統一したう えで患者に対応するようにアドバイスを受け，私達はで きるだけ時間を多くもつようにした，これにより，当初 は患者からはなかなか話しかけてはくれず私達の問いか けにうなずくのみであったが日毎に患者の表情もやわら かくなり，2 回目面接では抑うつ状態は軽隇し，口数は 少ないものの少しずつ笑顔がみられるようになった。そ の後, 退院したため面接は一時中断したが, 昭和 59 年 10 月入院し透析開始 1 週間後に 3 回目面接を行った. 3 回 目面接時は夫の死後間もない時期であったが動摇は比較 的小さいようで, 透析導入体調がよくなったと述べ, 以 前入院した時とは異なり周囲との交流も多く, 自分から 話しかけてくれるようになり，4回目面接では精神症状 も軽減していた。しかし，背中が時及痛くなるとの訴え
があり微熱が続いたため，イライラする表情をあらわす ようになってきた。 5 回目面接では心気状態を呈してお り，主治医が時々検査をし患者の話を聞くともっと良い 結果がでるでしょうとのアドバイスがあり，検査，処置 などの際，主治医，看護婦が一緒に説明にあたり話を聞 くようにした。これらのことより，医療者に対する不信 感もとれてきたようである.
症例 4 :
32 歳, 女性.

家族背景：夫 (入院中に離婚)，子供 1 人 (実家で母が 面倒みているが戸籍は夫側にある)。

現病歴：昭和 54 年 3 月全身疲労感, 脱力感, 全身浮腫 出現し，某医にて尿毒症を指摘され，当院に慢性系球体 腎炎による慢性腎不全の診断で血液透析療法を開始し た. 同年 8 月退院し外来通院, 同年 11 月左下腹部痛出現 し, 子宮筋腫と診断され, 11 月 30 日子宮卵管卵巣全摘出 術を行った。昭和 56 年 3 月退院となり外来通院していた が，同年 9 月肝機能障害のため入院となる.

経過：入院中に自分の病気を理由に自ら離婚を言いだ し，寂しさをまぎらわすためか無理に明るく振るまって いる様子がみられた。また子供の成長を楽しみにしなが らも，いつかは自分から離れていくのだろうということ を考えるとやりきれなくなると話していた，それにくわ え両側大腿骨頸部骨折を合併し，次第に精神的にいらだ ちがみられるようになり，1 回目の面接を行った。表 4 は本例の経過を表わしたものである.

初回面接では, 面接途中に唾を吐きかけ「死ぬ」と叫 び興奮状態となり，安定剤投与と継続した面接が必要だ ということであった，当初私達は興奮するのを恐れ，は れものにでもさわるような接し方をし，遠目に患者をみ ることが多く，対応に困惑していた，その後しばらくは 無気力状態が続いたが, 両側大腿骨頸部骨折しているこ とがわかり時々思いきり泣きたいなどと言っていた。 3 週間後の 2 回目面接では精神症状はやや軽減している 
表 4 面接時の精神症状と経過（症例 4)

\begin{tabular}{|c|c|c|c|}
\hline 面接回数 & $\begin{array}{c}1 \\
\text { (S 57.5.28) }\end{array}$ & $\begin{array}{c}2 \\
\text { (S 57.6.18) }\end{array}$ & $\begin{array}{c}3 \\
\text { (S } 57.11 .26 \text { ) }\end{array}$ \\
\hline 合併症 & $\begin{array}{l}\text { 両側大䬶骨頸部骨折 } \\
\text { (子宮筋腄・慢性関節りウマチ) }\end{array}$ & & 血中アミラーゼ值上昇 \\
\hline 心理状況 & 抑うつ, 悲観, 焦燥, 攻撃, 怒り & 抑うつ, 悲観, 焦燥, 攻撃, 怒り & 抑うつ, 悲観 \\
\hline $\begin{array}{l}\text { 精神科医の } \\
\text { アドバイス }\end{array}$ & $\begin{array}{l}\text { 継続した面接 } \\
\text { 安定剂投与 }\end{array}$ & $\begin{array}{l}\text { 抗うつ剂投与 } \\
\text { 足を何とかできたら }\end{array}$ & 大げさな態度に動じない \\
\hline 対 応 & $\begin{array}{l}\text { 精神状態の安定 } \\
\text { 鎮痛剂・安定剂の投与 }\end{array}$ & $\begin{array}{l}\text { 疼痛一プラゼボ使用 } \\
\text { 息子との面会 (夏休み) 手術決定 }\end{array}$ & $\begin{array}{l}\text { 手盛施行（左是） } \\
\text { リハビリ一意欲的 }\end{array}$ \\
\hline 結 果 & $\begin{array}{l}\text { はれものにさわるような接しうを } \\
\text { し，與震するのを琹れ，患者から } \\
\text { 遠さかかる }\end{array}$ & $\begin{array}{l}\text { 母親としての自賞 } \\
\text { 歩くことへの意欲 }\end{array}$ & リハビリ一意欲的 \\
\hline
\end{tabular}

が，骨折による大腿部痛が増強してきたことと離婚した ことが患者にとって心的負荷になっているものと考えら

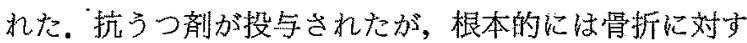
る治療が精神症状を軽隇させる最良の方法であると考え られ，整形外科医などと相談し人工骨頭置換術を行うこ ととした，その後手術の日程も決まり，息子の面会の回 数も增えたためか，母親としての自覚ももつようになり， 歩くことへの意欲も示すようになった. 11 月 9 日左人工 骨頭置換術加行的几術後 2 週間目, 3 回目の面接を行っ た，抑うつ，悲観が現われているものの，手術後の経過 が良好のためか，精神的に安定しているということで あった。術後のリハビリを開始し意欲もみられたが, 初 日に希望した運動が思うようにできなかうたことに ショックをうけ，興奮状態があらわれるようになうた。

「死にたい。どうでもよい」と涙ぐんだり，「食事は砂を かんでいるようで味覚がなく食べたくない」と拉否的な 態度を示す上うになったが, スタッフは大げさな態度に 動じないようにそぞにいて患者の話を聞くようにした。 このような対応をしたためか，精神的に少しずつ落着て きたようである。

\section{症例 5：20 歳, 男性.}

家族背景：両親，姉 2 人，弟 1 人.

現病歴：昭和 49 年 7 月 9 歳時, 膀胱・尿管逆流現象に よる慢性腎不全のため保存的療法を開始した。その後, 呼吸困難, 全身浮腫, BUN 上昇などの症状が出現し; 昭 和 50 年 6 月 10 歳時血液透析療法を開始した。同年 8 月 に外来透析に移行以後, シャントトラブル, 肝機能障害 などで 11 回の入退院をくり返し, 昭和 60 年 1 月透析中, 下腿の強固な筋痙戀が出現し入院となった。

経過：入院後も㾏攣が頻発したが意識は清明であっ た. 入院後，母親から聞いた話をまとめると，1) 弟が 成長してきた，2）患者は峬に依存しているが，姉が家
表 511 歳時と 20 歳時の症状と経過（症例 5 ）

\begin{tabular}{|c|c|c|c|}
\hline 月/日 & $\mathrm{S} .51$ 年 11 歳 弟出生時 & 月/日 & $\mathrm{S} .60$ 年 20 歳 青年期 \\
\hline $5 / 7$ & $\begin{array}{l}\text { 救急車で入院 } \\
\text { 全身浮腫・呼吸困難 }\end{array}$ & $1 / 19$ & 入院（透析中痓攣） \\
\hline $5 / 12$ & 胸部痛・苦悶・啼泣 & $1 / 20$ & 凐攣（間 \\
\hline $5 / 13$ & 母親の面会 & $1 / 22$ & 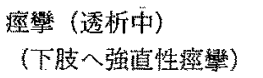 \\
\hline $7 / 5$ & $\begin{array}{l}\text { 外泊より帰院 } \\
\text { 上半身浮腫，咳濑 }\end{array}$ & & 痓攣（強直性） \\
\hline $9 / 1$ & 痤彎 17 回/月 & & $\begin{array}{l}\text { 母親の面会 } \\
\text { その後痓檠 }\end{array}$ \\
\hline $9 / 30$ & 母親面会 その後消失 & $1 / 25$ & $\begin{array}{l}\text { 精神科医面接 } \\
\text { 痤笔消失 }\end{array}$ \\
\hline $10 / 6$ & 退 院 & $\begin{array}{l}2 / 1 \\
4 / 5\end{array}$ & $\begin{array}{l}\text { 精神科医面接 } \\
\text { 退 院 }\end{array}$ \\
\hline
\end{tabular}

を出た，3）今年成人式であったが家族は気づかず，通 知は前日患者に届いたことなどであった。また，本例は 11 歳時弟の出生を契機に痙卛が頻発したことがあった が, 痙撃の状態が 11 歳時ときわめて類似していたことか ら，精神的な原因が涇卛を㧍こす誘因となっているので はないかと考元面接を行った。表 5 は本例の 11 歳時と現 在の症状と経過を示したものである。

患者は家庭内では特に問題ないと言っでおり, 誰にも 話しできず恼んでいたことは，バスで通院途中に会った 女性が好きになり，その女性が看護婦に似ているという ことであった。その看護婦がそばにくるとドキドキする と話していたことから，体が小さくても成人男性として 接するように冷やかさないようにとアドバイスを受け た。面接後から核摹が消失し, また, 看護婦に打ち明 けた後は気分が楽になったと言っていた。

\section{考察}

透析治療は生涯にわたり継続されなければならず，患 
者はその間に生じてくる様々な問題を抱え，複雑な心理 的影響を及ぼしていることが多い3). 透析患者の精神症 状については 26〜40 歳の働き盛りの年齢層や 18 歳未満 の子供を有する例，重篤な合併症を有する例，離婚例な どで抑うつ，悲観，怒り，焦燥，攻撃，自殺念慮などが 多いことを平山ら ${ }^{1)}$ が報告しているが，その背景にはそ れぞれの症例で異なった問題点があり，それが精神的負 荷となってさまざまな症状を呈してくることを常に念頭 に置く必要がある4).ここに示した 5 症例ごとに考察を 加えてみると，症例 1 は妻子から見捨てられ夫，親とし ての役割岥失が問題となった例である。このような症例 に対しては，家族への積極的な働きかけが大切である。 楽しみに待っていた妻子の面会もなく精神症状が出現し たが，面会や外泊時の対話などをすすめることにより精 神症状の軽快をみた。すでに家庭内での役割はないと判 断された症例を受け入れることは家族の精神的負担とな るが患者を励まし，暖かく迎え入れる姿勢がなにより患 者の精神的な支えになっている2こことを十分に説明する 必要がある.しかし，家族の問題に私達がどの程度まで かかわりをもっていくべきかも常に見極めながら慎重に 対処していくことも大切なことである.

症例 2 は不定愁訴をくり返したが，家族内に精神病を もった甥の存在が最大の原因と考えられ，患者のもつ問 題点をいかに早く見い出すかが重要であると改めて考え させられた例である。したがって主治医や看護婦が患者 と接する時間を多くして, 患者が「一生縣命自分の病気 を直してくれている」と感じた時などに一時的に精神症 状は軽減しても, 根本的な解決とはならなかったわけで ある。

症例 3 は医療スタッフの治療態度に不信感を抱いた例 で医療スタッフが統一した見解のもとで検查，処置など の説明を十分に行うことにより不信感もとれ，また，患 者の話を聞き接する時間をもつことにより，患者との信 頼関係を保つことができるようになった症例である。こ のことは，私達透析医療にたずさわる者が透析療法への 導入時に常に心がけていかなければならない点である。 医療スタッフにとっては日常の出来事である透析療法へ の導入が，患者にとってはきわめて重大で非日常的体験 であることを常に念頭に扔き透析療法の必要性や，今後 の展望などについて十分な説明をするとともに，これが 統一した見解のもとで行われることが重要である。これ によって，透析療法への導入が円滑に行えるばかりでな くその後の患者との信頼関係を築く上での基礎となって いく，本症例の場合も透析療法への導入による精神症状 の悪化はなく，むしろ全身状態の改善によって精神症状 も軽快を示しており，円滑な透析療法への導入がなされ
たことが示された。

症例 4 は重篤な合併症の出現が問題となった例であ り, 合併症に対する治療を優先することが精神症状の改 善を計ることができる唯一の方法であることを痛感させ られた。

症例 5 は身体が小さく病気をもっているという劣等感 を有しながら恋愛感情を抱いたのを契機に発症した例で あり，この症例に対しスタッフはいつまでも小児报いを したこともあり，呼び名も苗字で呼ぶように年齢にみ あった接し方をしていくことが必要であると思われた。

以上の 5 症例は私達の経験したほんの一部にすぎない が，様々な問題が根底にありそれに伴って出現する精神 症状の変化を私達医療者は正確にとられ，その原因を十 分に理解しながら対応していくことが大切であり，こう することによりはじめて患者は医療側に対し心を開き， 精神症状の軽減が得られていくものと考えられる。この ような過程の中で医療スタッフ間での話し合いにより， 統一した見解をもって対応していくことも患者との信頼 関係を保っていくために重要であり，また家族への面会 や外泊などの働きかけも必要となってくる.

このことは症例 3 のごとく医療側に対し強い不信感を もっている症例や，症例 4 のようにつぎつぎと合併症を 発病した例などに顕著に示されているものと思われる。 また症例 1，2 のように家庭内の問題がその原因となっ ている場合には，医療側が関与しうる限界もあることか ら，家庭内での問題解決に待たねばならないことにより 積極的な働きかけも必要となる。さらに症例 5 のように 透析療法も長期にわたった場合，患者の年齢，家族環境 の変化に応じて対応も変えていく必要のあることも示さ れた。

\section{結語}

私達が行ってきた精神症状に対応した看護について 5 症例を提示し述べてきたが，実際には必ずしも十分で あったとはいい難く多くの反省点を含んでいる。しかし 本来患者がもっている問題や出現してくる精神症状を正 確に把握し，適切な対応をすることにより，徐々にでは あるが必ず改善してくることも事実である，日常の看護 にあたって，援助する役割を担う看護婦は現象に対する 表面的な問題のとら方方でなく，人間の本質に目を向け たアプローチが重要であり ${ }^{2)}$ ，今後はこのような点に十 分な配慮をしながら看護にあたってきたいと考えてい る.

稿を終るにあたり，御指導ならびに御校閲をいただいた弘 前大学医学部泌沓器科教授舟生富寿先生に深甚なる謝意を表 わすとともに，終始暖かい御指導と御教示いただきました弘 
前大学医学部精神神経科, 兼子 直先生, 鷹揚郷㱟研究所弘 前病院院長, 平山順朗先生に愿く御礼申し上げます。

本論文の要旨は第 30 回人工透析研究会総会, ワークショッ プ2「長期透析患者の看護と問題点」において発表した。

\section{文献}

1）平山順朗, 小山内幸, 植松和家, 鈴木唯司, 舟生富 寿, 兼子 直: 透析患者の精神症状とその対応. 透
析会誌, $18: 301-308,1985$.

2）舘山俊子，佐藤優子，田沢八チエ：長期透析患者の 再入院の問題点. ナースステーション, $12: 261-265$, 1982.

3）五十嵐杽子：透析患者にみられる精神症状と看護。 看護技術, $24: 69-75 ， 1978$.

4）春木繁一: 透析患者の心理と精神症状. p. 1-9, p. 99-119, 中外医学社, 1982. 